\title{
Van NHG-dossier Coronavirus naar NHG-Standaard COVID-19
}

NHG-coronateam/NHG-werkgroep COVID-19

Het NHG-dossier Coronavirus [COVID-19] voorzag huisartsen in 2020 en de eerste helft van 2021 van actuele informatie over SARS-CoV-2. Nu de kennis over 'acute' COVID-19 op meer wetenschappelijk onderzoek en ervaring is gebaseerd, en de ontwikkelingen minder turbulent zijn, heeft het NHG besloten het medisch-inhoudelijke deel van het coronadossier in te bedden in de reguliere processen en producten. De ontwikkeling van de NHG-Standaard COVID-19 is hiervan het resultaat. In dit artikel gaan we met name in op de omzetting van het dossier naar een reguliere NHG-Standaard, waarvan de belangrijkste kernboodschappen verderop in dit artikel vermeld staan.

Op 27 februari 2020 wordt de eerste patiënt met COVID-19 in Nederland geïdentificeerd. In de 16 maanden die volgen, meldt de GGD in totaal 1.684.366 personen met SARSCoV-2. ${ }^{1}$ Het overgrote deel van de patiënten maakt COVID-19 thuis (of in een instelling) door. Een deel hiervan neemt contact op met de huisartsenpraktijk en wordt gezien in de spreekkamer, tijdens een visite of middels (beeld)bellen. De huisarts monitort patiënten, verwijst de ernstig zieken naar de tweede lijn en geeft begeleiding in de terminale fase. Op 29 juni 2021 waren tot dan toe 57.851 bewezen of verdachte COVID-19-patiënten opgenomen op de verpleegafdeling van een Nederlands ziekenhuis, van wie 7.782 patiënten overleden. Voor 12.841 patiënten was een ic-opname nodig; 3.602 van deze patiënten overleden. ${ }^{2}$

\section{VRAGEN UIT HET LAND ALS BRON VOOR HET CORONADOSSIER} In het begin van de pandemie heerste er veel onzekerheid en onduidelijkheid over de ziekte COVID-19. Veel huisartsen namen contact op met vragen, opmerkingen, kritiek en suggesties. In heel 2020 ontving het NHG-coronateam 1330 vragen over COVID-19. Het bleek waardevolle input om knelpunten te identificeren en om adviezen over de diagnostiek, behandeling, het testbeleid en infectiepreventie te formuleren. Andere onderwerpen waren de organisatie van de zorg en de psychosociale zorg voor patiënten en hulpverleners. Later kwamen

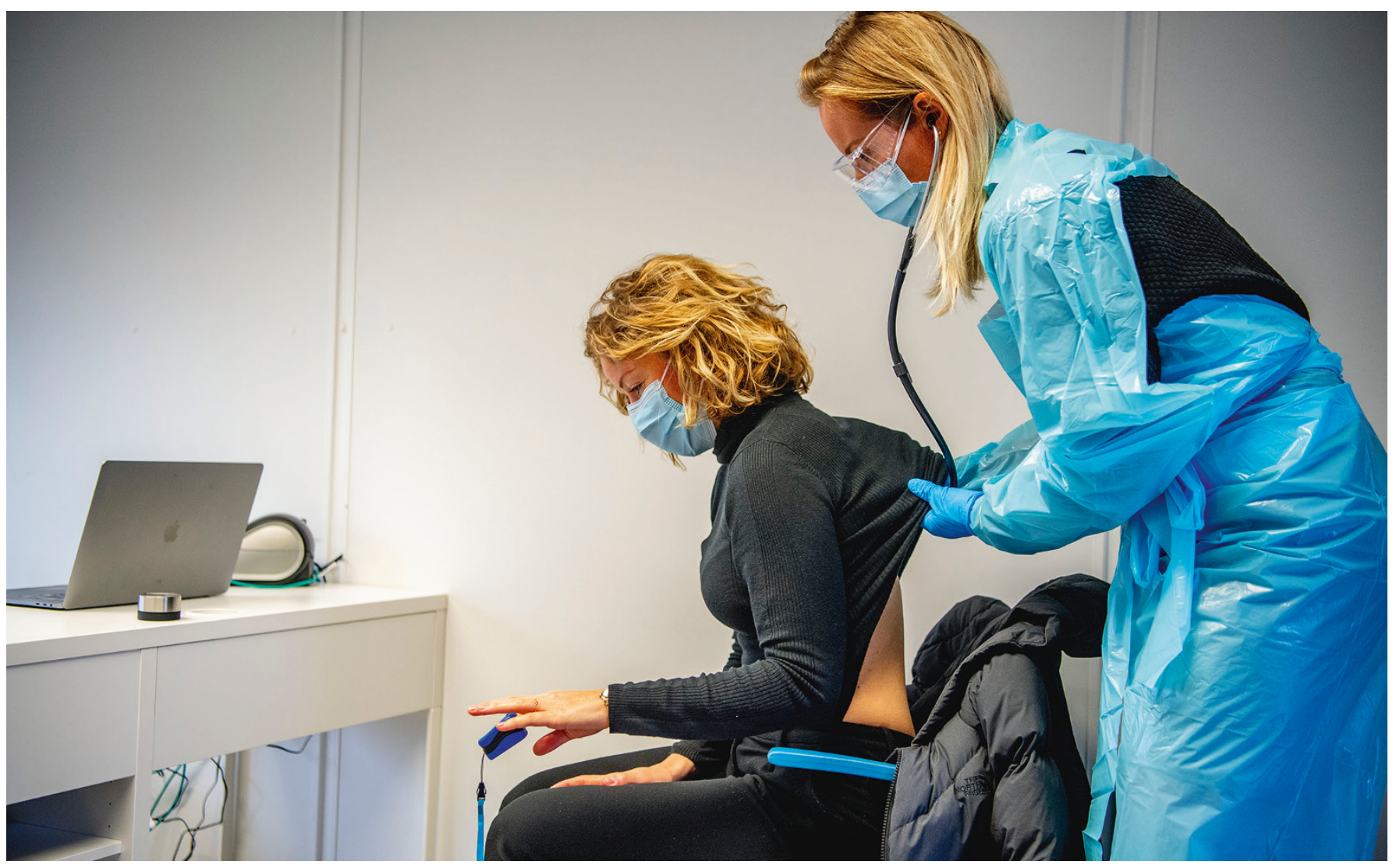

De scope van de NHG-Standaard COVID-19 is de diagnostiek en behandeling van COVID-19 in de acute fase. 
$\iint \begin{aligned} & \text { bohn } \\ & \text { stafleu }\end{aligned}$

C. van loghum

Cohn

stafleu

van loghum

bohn

stafleu

van loghum

CSe bohn

Stafleu

van loghum

bohn

stafleu

- van loghum

cef bohn

S) stafleu

IL van loghum

cCe bohn

S) stafleu

. van loghum

cCe bohn

D) stafleu

CL van loghum

cCe bohn

S) stafleu

van loghum

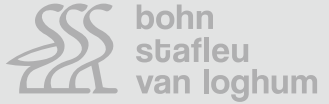

cCehn bohn

9) stafleu

van loghum

3S bohn

C. van loghum

cef bohn

9) stafleu

- van loghum

3SS bohn

CL van loghum

bohn

stafleu

van loghum

cCe bohn

stafleu

van loghum
CCS bohn

stafleu

CL van loghum

$\int S$ bohn

van loghum

$\int S \begin{aligned} & \text { bohn } \\ & \text { stafleu }\end{aligned}$

van loghum

cCe bohn

stafleu

CL van loghum

CSS bohn

Plafleu

van loghum

CSC bohn

stafleu

van loghum

CSS bohn

stafleu

CCS bohn

8tafleu

L van loghum

$\int S$ bohn

Lan loghum
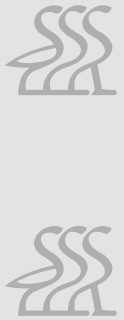

$\sum\left\{\begin{array}{l}\text { bohn } \\ \text { stafleu } \\ \text { van loghum }\end{array} \sum\left\{\begin{array}{l}\text { bohn } \\ \text { stafleu } \\ \text { van loghum }\end{array}\right.\right.$

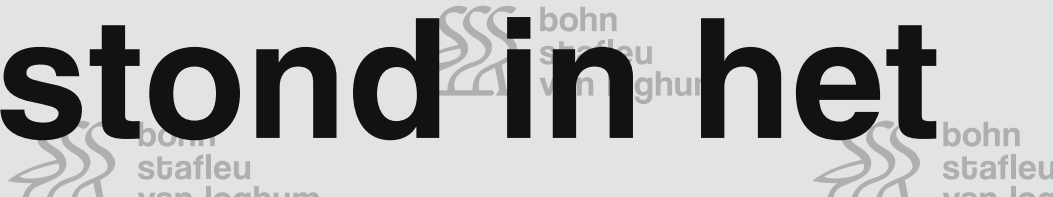

stafleu
van loghum

$\int S$

$\int \mathcal{C}$

$\sum \int$

CSe bohn $\begin{aligned} & \text { bufleu } \\ & \text { van loghur }\end{aligned}$

cohn

stafleu

van loghum

SCL

Cef bohn

PU stafleu

van loghum

CCe bohn

8 stafleu

L van loghum

SCS bohn

suafleu

cec bohn

8tafleu

C. van loghum

SSS bohn

van loghum

eC bohn

8 stafleu

1. van loghum

SCS bohn

8 stafleu

1. van loghum

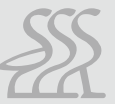

SSS bohn

van loghum

cec bohn

8) stafleu

CL van loghum

$\int S \begin{aligned} & \text { bohn } \\ & \text { stafleu }\end{aligned}$

van loghum

\$SS

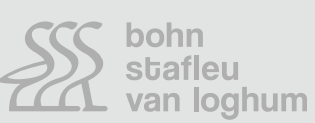

ce bohn

8 stafleu

1. van loghum 
$\iint \begin{aligned} & \text { bohn } \\ & \text { stafleu }\end{aligned}$

C. van loghum

Cohn

stafleu

van loghum

bohn

stafleu

van loghum

CSe bohn

Stafleu

van loghum

bohn

stafleu

- van loghum

cef bohn

S) stafleu

IL van loghum

cCe bohn

S) stafleu

. van loghum

cCe bohn

D) stafleu

CL van loghum

cCe bohn

S) stafleu

van loghum

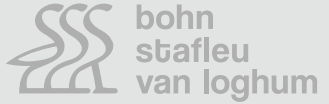

cCehn bohn

9) stafleu

van loghum

3S bohn

C. van loghum

cef bohn

9) stafleu

- van loghum

3SS bohn

CL van loghum

bohn

stafleu

van loghum

cCe bohn

stafleu

van loghum
CCS bohn

stafleu

CL van loghum

$\int S$ bohn

van loghum

$\int S \begin{aligned} & \text { bohn } \\ & \text { stafleu }\end{aligned}$

van loghum

cCe bohn

stafleu

CL van loghum

CSS bohn

Plafleu

van loghum

CSC bohn

stafleu

van loghum

CSS bohn

stafleu

CCS bohn

8tafleu

L van loghum

$\int S$ bohn

Lan loghum
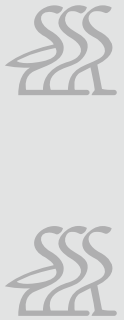

$\sum\left\{\begin{array}{l}\text { bohn } \\ \text { stafleu } \\ \text { van loghum }\end{array} \sum\left\{\begin{array}{l}\text { bohn } \\ \text { stafleu } \\ \text { van loghum }\end{array}\right.\right.$

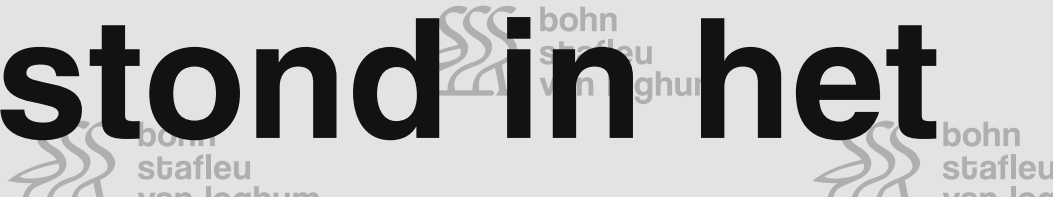

stafleu
van loghum

$\int S$

$\int \mathcal{C}$

$\sum \int$

CSe bohn $\begin{aligned} & \text { bufleu } \\ & \text { van loghur }\end{aligned}$

cohn

stafleu

van loghum

SCL

Cef bohn

PU stafleu

van loghum

CCe bohn

8 stafleu

L van loghum

SCS bohn

suafleu

cec bohn

8tafleu

C. van loghum

SSS bohn

van loghum

eC bohn

8 stafleu

1. van loghum

SCS bohn

8 stafleu

1. van loghum



SSS bohn

van loghum

cec bohn

8) stafleu

CL van loghum

$\int S \begin{aligned} & \text { bohn } \\ & \text { stafleu }\end{aligned}$

van loghum

\$SS

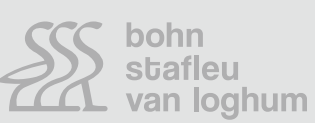

ce bohn

8 stafleu

1. van loghum 


\section{KADER 1 KERNBOODSCHAPPEN}

- COVID-19-patiënten met een lage saturatie lijken geregeld niet benauwd.

- Verricht diagnostiek naar COVID-19 bij patiënten bij wie u een vermoeden hebt van COVID-19 en die u ziet omdat een klinische inschatting gewenst is.

- De PCR-test heeft de voorkeur boven de antigeensneltest.

- Wees alert op verslechtering na 7 tot 8 dagen [range 5 tot 12 dagen].

- Bij een saturatie $<92 \%$ tot $94 \%$ en/of ademfrequentie > 24/minuut en/of klinisch snelle achteruitgang, is ziekenhuisopname geïndiceerd.

- Denk bij dyspneu en vermoeden van COVID-19 ook aan andere of bijkomende oorzaken, zoals een acuut coronair syndroom, longembolie, hartfalen, longaanval astma/COPD of een luchtweginfectie door een andere verwekker [bacterieel/viraal].

daar ook vragen bij over nazorg, long (langdurige) COVID, kennislacunes en natuurlijk de vaccinaties. De informatie over al deze onderwerpen vormde samen het NHG-dossier Coronavirus, een vaste plek voor de huisartsenpraktijk voor informatie over COVID-19.

Om de samenhang met adviezen van andere organisaties te bevorderen, werkte het NHG tijdens deze periode doorlopend samen met onder andere het RIVM, de FMS, de LHV en InEen. Ook werd al deze informatie toegankelijk gemaakt voor patiënten via Thuisarts.nl.

\section{ACTUALISATIES}

Voortschrijdende inzichten en ontwikkelingen vroegen en vragen om frequente aanpassingen van het dossier. Tijdens de eerste golf werden wijzigingen meerdere keren per week, ook in het weekend, doorgevoerd. Dit vormde een uitdaging voor het coronateam van het NHG, maar zeker ook voor de huisarts om aangesloten te blijven.

\section{VAN DOSSIER NAAR STANDAARD}

Ondanks de komst van werkzame COVID-19-vaccins wordt SARS-CoV-2 naar alle waarschijnlijkheid een endemisch virus. Mede hierom besloot het NHG eind 2020 tot de ontwikkeling van de NHG-Standaard COVID-19. Een geautoriseerde richtlijn die aansluit op gangbare werkprocessen en die de huisarts, zoals alle andere NHG-Standaarden, in een vertrouwde structuur ondersteuning biedt tijdens het spreekuur. De NHG-Standaard kwam via een versnelde procedure tot stand: de ontwikkeling van de standaard kon plaatsvinden in 6 maanden door het voorwerk dat het coronateam voor het NHG-dossier Coronavirus al had verricht. Net als bij andere NHG-Standaarden is ook deze standaard ontwikkeld door een werkgroep. Die bestond uit NHG-medewerkers van het
KADER 2 GERELATEERDE INFORMATIE

- NHG-dossier Coronavirus [corona.nhg.org]

- Thuisarts.nl [thuisarts.nl/corona]

- NHG E-learning COVID-19 [nhg.org/webwinkel]

cluster Richtlijnontwikkeling \& Wetenschap die al betrokken waren bij het coronadossier, externe huisartsen/experts en een longarts.

\section{SCOPE VAN DE STANDAARD: ACUTE FASE}

De scope van de NHG-Standaard COVID-19 is de diagnostiek en behandeling van COVID-19 in de acute fase. De acute fase duurt tot ongeveer 4 weken na aanvang van de klachten. Zie voor de kernboodschappen uit de standaard [kader 1]. De nazorg komt aan bod in de multidisciplinaire richtlijn (MDR) Nazorg COVID-19, die de FMS, de LAN en het NHG momenteel samen ontwikkelen. Deze wordt in een later stadium aan de standaard toegevoegd.

\section{'LEVENDE' STANDAARD}

Flexibiliteit van het coronadossier was noodzakelijk om de huisarts van actuele informatie te voorzien. Om deze flexibiliteit zo veel mogelijk vast te houden, is de NHG-Standaard COVID-19 een 'levende' richtlijn, die vaker dan de meeste andere richtlijnen geactualiseerd wordt. Hoe vaak herziening nodig is, hangt af van het verdere beloop van de pandemie, de vaccinatiegraad en nieuwe inzichten voortkomend uit wetenschappelijk onderzoek.

\section{AFGESLANKT NHG-DOSSIER CORONAVIRUS}

Het coronadossier blijft in een afgeslankte vorm bestaan met het laatste nieuws en (achtergrond)informatie over onder meer nazorg, infectiepreventie, organisatie van de zorg en psychosociale zorg.

\section{LITERATUUR}

1. RIVM. https://www.rivm.nl/coronavirus-covid-19/actueel/wekelijkse-update-epidemiologische-situatie-covid-19-in-nederland, geraadpleegd op 29 juni 2021.

2. Stichting Nationale Intensive Care Evaluatie (NICE). https://www. stichting-nice.nl, geraadpleegd op 29 juni 2021.

Raadpleeg de volledige versie van de NHG-Standaard COVID-19 op https://richtlijnen.nhg.org/standaarden/COVID-19.

NHG-werkgroep COVID-19. Van NHG-dossier Coronavirus naar NHG-Standaard COVID-19. Huisarts Wet 2021;64[8]:58-61. DOI:10.1007/s12445-021-1012-3.

Mogelijke belangenverstrengeling: niets aangegeven. De NHG-werkgroep bestond uit [op alfabetische volgorde]: EI Bouazzaoui L, Bouma M, Cals J, Geersing G, Greving J, Kok-Pigge A, Loogman M, Nijs M, Platteel T, Verheij T. 